\title{
Porous Ceramic Supports for Membranes Prepared from Kaolin (DD3) and Calcite Mixtures
}

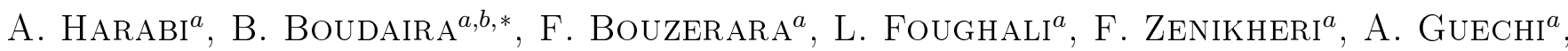 \\ B. GHOUIL ${ }^{a}$, S. CONDOM ${ }^{c}$ \\ ${ }^{a}$ Ceramics Laboratory, Physics Department, Faculty of Exact Science, \\ Constantine University 1, Constantine 25000, Algeria \\ ${ }^{b}$ Department of Matter Sciences, Faculty of Exact Science \& SNV, Biskra University, Biskra 7000, Algeria \\ ${ }^{c}$ Institut Européen des Membranes, UMR 5635 CNRS ENSCM UMII, \\ 1919 Route de Mende, 34293 Montpellier Cedex 5, France
}

\begin{abstract}
The supports for microfiltration (MF) and ultrafiltration (UF) were prepared with local kaolin (Djebel Debagh: type 3: DD3) and calcium carbonate $\left(\mathrm{CaCO}_{3}\right)$ mixtures. The choice of these materials is based on their natural abundance (low price). In this work, the tubular ceramic supports were prepared by the extrusion method. The sintering was carried out for 2 hours, at temperatures laying between 1150 and $1300{ }^{\circ} \mathrm{C}$. They are then characterized by various techniques: mercury porosimetry, scanning electron microscopy and x-ray diffraction. The obtained results revealed that the main phase formed during the sintering step was anorthite with a minor phase of mullite. Moreover, it has been found that supports sintered at temperatures less than $1300{ }^{\circ} \mathrm{C}$ had interesting characteristics; an average pore size ranged between $3.91-8.56 \mu \mathrm{m}$, a porosity ratio of $42.0-50.4 \%$, a flexural strength $\approx 67-77 \mathrm{MPa}$ and the pore size distribution is bimodal type. According to their average pore sizes, they may be used either as supports for MF or UF membranes.
\end{abstract}

DOI: $10.12693 /$ APhysPolA.127.1164

PACS: 81.05.Rm, 81.05.Je, 81.20.Hy, 81.05.Bx

\section{Introduction}

The ceramic products are extremely interesting in the field of the membrane supports because of their mechanical resistance, chemical inertia, long working life and thermal stability [1]. A membrane support provides mechanical strength to a membrane top-layer to withstand the stress induced by the pressure difference applied over the entire membrane and must simultaneously have a low resistance to the filtrate flow [2]. A significant effort was then provided these last years in membrane technology field in order to find out new porous ceramics materials at low price [3] because the marketed supports are generally manufactured from compounds such as alumina $\left(\mathrm{Al}_{2} \mathrm{O}_{3}\right)$, cordierite $\left(2 \mathrm{MgO} \cdot 2 \mathrm{Al}_{2} \mathrm{O}_{3} \cdot 5 \mathrm{SiO}_{2}\right)$ and mullite $\left(3 \mathrm{Al}_{2} \mathrm{O}_{3} \cdot 2 \mathrm{SiO}_{2}\right)[4-8]$. In order to decrease this cost and to evaluate our natural resources, many works have already been carried out [9-27]. This study is related to the development of ceramic [28] supports using Algerian natural materials (kaolin DD3 type) and calcium carbonate $\left(\mathrm{CaCO}_{3}\right)$.

\section{Experimental procedures}

The natural kaolin (DD3) and calcium carbonate $\left(\mathrm{CaCO}_{3}\right)$ powders used in this study were obtained from Guelma and Constantine regions (Algeria), respectively. The chemical analysis of this kaolin indicates that silica and alumina are the major components [29] of the kaolin.

*corresponding author; e-mail: boudaira.boukhemis@gmail.com
The particle size distribution of these materials was determined by the Dynamic Laser Beam Scattering (DLBS) technique. This method gave an average particle size in the order of 1.2 and $4.8 \mu \mathrm{m}$, respectively.

The prepared plastic paste is based on a mixture of $[6]$ kaolin (DD3) (79 wt.\%), calcium carbonate $\left(\mathrm{CaCO}_{3}\right)$ (15 wt.\%) and organic additives (3 wt.\% of amijel derived from methylcellulose (The Dow Chemical Company), 3 wt.\% of methocel derived from starch (Cplus 12072, Cerestar)) with a progressive addition of water to adjust the rheological properties of the paste to allow the shaping [30].

Tubular ceramic supports were made by extrusion method [31] where the powders were mixed with certain organic additives which can be extruded to fabricate a porous tubular configuration with a highly uniform porous structure [32].

After drying at room temperature for $24 \mathrm{~h}$, the supports were sintered at different temperatures ranging from 1150 to $1300^{\circ} \mathrm{C}$ increasing with a step of $50{ }^{\circ} \mathrm{C}$ for $2 \mathrm{~h}$. A temperature plate at $250^{\circ} \mathrm{C}$ [33] for 10 min was dictated in order to eliminate the added organic materials and to avoid the micro-cracks in the samples. The choosing sintering rate was $2{ }^{\circ} \mathrm{C} / \min [34]$.

\section{Results and discussion}

X-ray diffraction was used to identify the formed phases in samples, heated at various temperatures. The main phase detected in samples that were fired at which different temperatures was anorthite $\left(\mathrm{CaO} \cdot \mathrm{Al}_{2} \mathrm{O}_{3} \cdot 2 \mathrm{SiO}_{2}\right)$ which is a predominant phase where the diffraction peaks increase when the sintering temperature increased with 
the presence of a small amount of mullite $\left(3 \mathrm{Al}_{2} \mathrm{O}_{3} \cdot 2 \mathrm{SiO}_{2}\right)$ phase, as shown in Fig. 1.

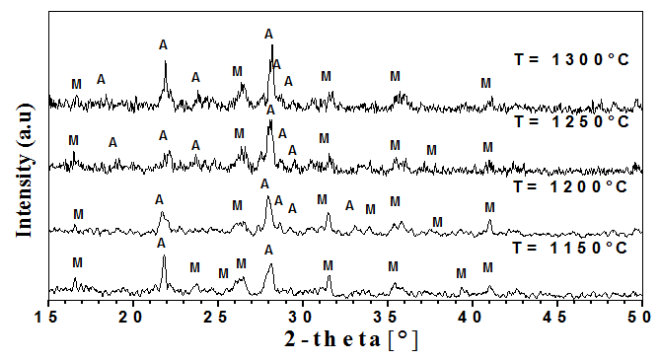

Fig. 1. XRD spectra of samples sintered at different temperatures for $2 \mathrm{~h}$. A-Anorthite; M-Mullite.

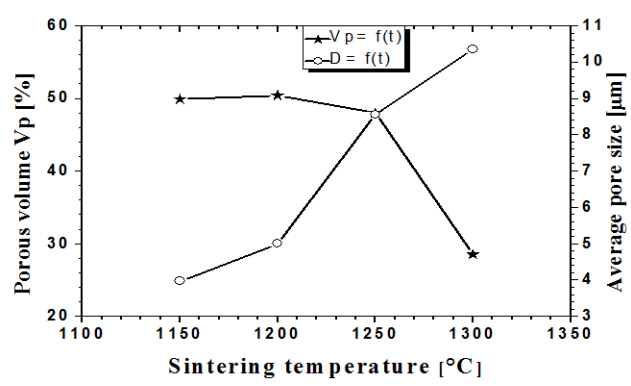

Fig. 2. Porous volume (\%) and average pore size vs. sintering temperature.

For the development of high quality supports the following properties are of major importance: pore size distribution, porosity, surface quality with the absence of large defects or large pores, a mechanical and a chemical stability [4]. Total porosity and average pore size have been determined by mercury intrusion porosimetry for supports sintered at different temperatures for $2 \mathrm{~h}$. The obtained results are illustrated in Fig. 2. This figure shows, generally, that there is an increase in average pore size (APS) and a decrease in total porosity in samples, when the sintering temperature is increased [35]. This behavior is due to the decomposition of kaolin, and calcium oxide which leads to the formation of crystalline phases such as anorthite and mullite.

The presence of the above mentioned phases encourage the liquid phase formation. This reaction sequence and the reduced liquid phase formation improve the ceramic bodies with porosity and a wider firing range [36]. The increase in APS is also confirmed by SEM micrographs illustrated in Fig. 3.

In the range of sintering temperature $\left(1150-1250{ }^{\circ} \mathrm{C}\right)$, the pore size and the porosity are acceptable. For example, the supports which were sintered at $1150^{\circ} \mathrm{C}$ had a porosity ratio of $\approx 49.9 \%$ and an APS around $4.0 \mu \mathrm{m}$. In the other hand, the supports which are sintered at $1300{ }^{\circ} \mathrm{C}$ had a porosity ratio of $\approx 28.5 \%$ and an APS around $10.3 \mu \mathrm{m}$. So it can be said that the addition of $\mathrm{CaCO}_{3}$ to kaolin improves the porosity ratio of supports which is less than $50 \%$. The pores characterization may be divided into three main features (cate-

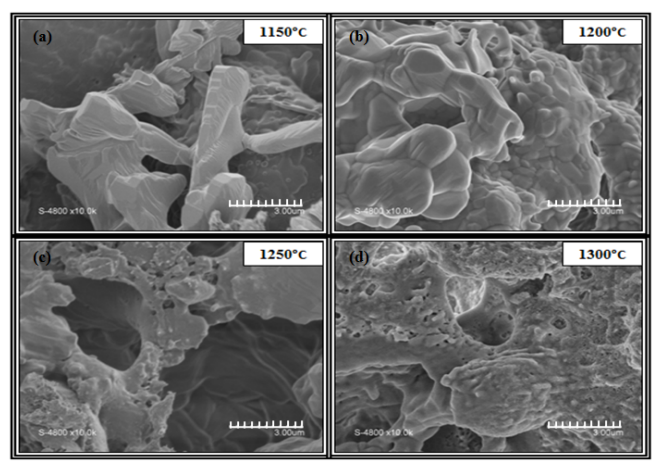

Fig. 3. SEM micrographs of surface supports, sintered at different temperature for $2 \mathrm{~h}$.

gories). These consist of a total porosity, an APS and a modal distribution of pore size (Fig. 4). The pore size distribution modal may also be classified into three distinct modals; single or Gaussian distribution, bi-modal and multi-modal pore size having distributions. The single (mono) modal of pore size distribution (SMPSD) is generally obtained for samples which have a uniform pore size distribution. When pore volume (\%) is plotted against pore size, the curve is characterised by a single peak (Fig. 4b). However, the bi-modal of pore size distribution (BMPSD) is characterised by two different or overlapping peaks. This means that there are two classes of pore size distribution (Fig. 4a, 4c and 4d). Finally, the multimodal of pore size distribution (MMPSD) is characterized by the presence of more than two distinct or overlapping peaks [2].
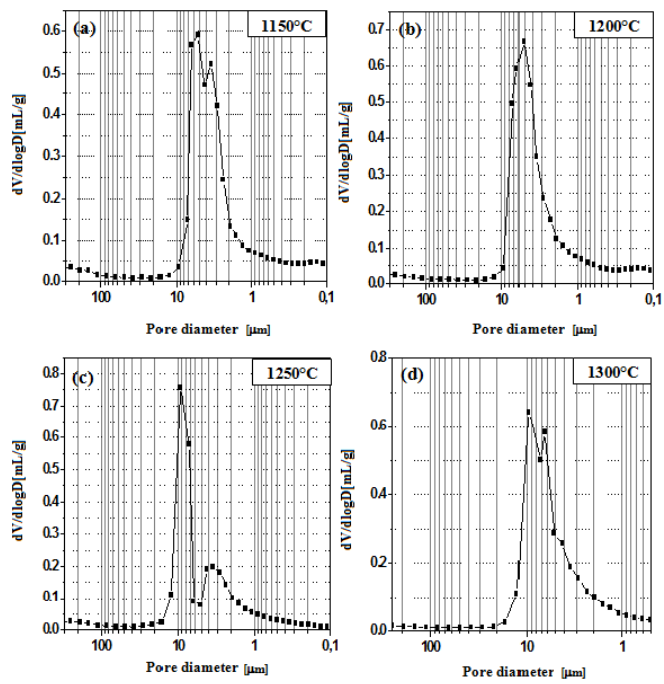

Fig. 4. Pore size distribution in samples, sintered at different temperatures for $2 \mathrm{~h}$.

Figure 5 shows that there are two different stages. Following rapid increase in flexural strength is reached for samples sintered at temperatures ranging from 1100 to $1200^{\circ} \mathrm{C}$, the mechanical properties have been considerably improved. This improvement may mainly due to 
the effect of sintering in samples where materials grains have been densified, and this is due to stability in the pore size and porosity ratio, and this is well shown in Fig. 3a and $3 \mathrm{~b}$. However, in the range $\left(1200\right.$ and $\left.1250^{\circ} \mathrm{C}\right)$ the flexural strength decreased sharply. This sharp decrease may be due to the considerable increase in pores volume (Fig. 3c and 3d).

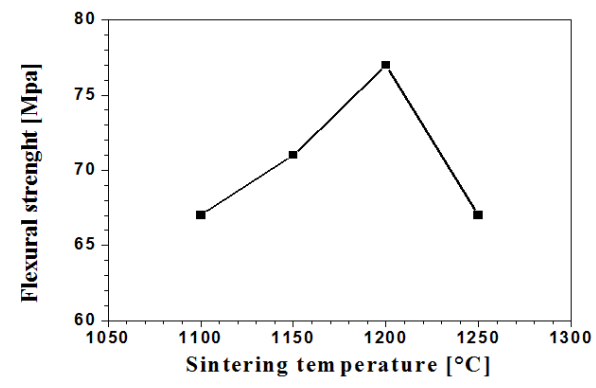

Fig. 5. Flexural strength as a function of sintering temperature.

\section{Conclusions}

In this study, supports for MF and UF have been prepared from local raw materials (Kaolin (DD3) and Calcium carbonate mixtures) by the use of extrusion method where tubular configuration were obtained. It has been found that supports sintered at $1150-1250^{\circ} \mathrm{C}$ had interesting characteristics; an APS of 3.91-8.56 $\mu \mathrm{m}$, a porosities ratio of $42.0-50.4 \%$, a flexural strength range $\approx 67-77 \mathrm{MPa}$ and the pore size distribution is monomodal type (samples sintered at $1200^{\circ} \mathrm{C}$ ) and bi-modal type (for other sintering temperatures). These supports can be used for MF and UF.

\section{References}

[1] A. Belouatek, N. Benderdouche, A. Addou, A. Ouagued, N. Bettahar, Microporous and Mesoporous Materials 85, 163 (2005).

[2] F. Bouzerara, A. Harabi, S. Achour, A. Larbot, J. Eur. Cer. Soc. 26, 1663 (2006).

[3] S. Masmoudi, R. Ben Amar, A. Larbot, H. El Feki, A. Ben Salah, L. Cot, J. Membr. Sci. 247, 1 (2005).

[4] T.V. Gestel, C. Vandecasteele, A. Buekenhoudt, C. Dotremont, J. Luyten, R. Leysen, J. Membr. Sci. 207, 73 (2002).

[5] G.E. Romanos, Th.A. Steriotis, E.S. Kikkinides, N.K. Kanellopoulos, V. Kasseelouri, J. Eur. Ceram. Soc. 21, 119 (2001).

[6] S.H. Zhong, C.F. Li, X.F. Xiao, J. Membr. Sci. 199, 53 (2002).

[7] N. Saffaj, S.A. Younssi, A. Albizane, A. Messouadi, M. Bouhria, M. Persin, Desalination 168, 259 (2004).

[8] T. Mohammadi, A. Pak, Sep. Purif. Technol. 30, 241 (2003).

[9] A. Harabi, S. Achour, J. Mater. Sci. Lett. 18, 955 (1999).

[10] M.R. Boudchicha, S. Achour, A. Harabi, J. Mater. Sci. Lett. 20, 215 (2001).

[11] A. Mecif, J. Soro, J.P. Bonnet, A. Harabi, J. Am. Ceram. Soc. 93, 1306 (2010).
[12] S. Achour, A. Harabi, N. Tabet, Mater. Sci. and Eng. B 42, 289 (1996).

[13] O. Toumiat, S. Achour, A. Harabi, N. Tabet, M. Boumaour, M. Maallemi, Nanotechnology 17, 658 (2006).

[14] O. Bourbia, S. Achour, N. Tabet, M. Parlinska, A. Harabi, Thin Solid Films 515, 6758 (2007).

[15] A. Harabi, F. Bouzerara, S. Condom, Des. Wat. Treat. 6, 222 (2009)

[16] F. Bouzerara, A. Harabi, S. Condom, Des. Wat. Treat. 12, 415 (2009).

[17] A. Harabi, A. Guechi, S. Condom, Procedia Engineering 33, 220 (2012).

[18] A. Harabi, F. Zenikheri, B. Boudaira, F. Bouzerara, A. Guechi, L. Foughali, J. Eur. Ceram. Soc. 34, 1329 (2014).

[19] F.Z. Mezahi, H. Oudadesse, A. Harabi, A. LucasGirot, Y. Le Gal, H. Chaair, G. Cathelineau, J. Therm. Anal. Calorim. 95, 21 (2009).

[20] F.Z. Mezahi, H. Oudadesse, A. Harabi, J. Appl. Ceram. Technol. 9, 529 (2012).

[21] A. Harabi, S. Chehlatt, J. Therm. Anal. Calorim 111, 203 (2013).

[22] A. Harabi, S. Zouai, Int. J. Appl. Ceram. Technol. 11, 31 (2014)

[23] A. Harabi, D. Belamri, N. Karboua, F.Z. Mezahi, J. Therm. Anal. Calorim. 104, 283 (2011).

[24] A. Lucas-Girot, F.Z. Mezahi, M. Mami, H. Oudadesse, A. Harabi, M. Le Floch, Journal of Non-Crystalline Solids 357, 3322 (2011).

[25] F.Z. Mezahi, A. Lucas-Girot, H. Oudadesse, A. Harabi, Journal of Non-Crystalline Solids $\mathbf{3 6 1}$, 111 (2013).

[26] S. Kitouni, A. Harabi, Cerâmica 57, 453 (2011).

[27] F. Bouzerara, A. Harabi, B. Ghouil, N. Medjemem, B. Boudaira, S. Condom, Procedia Engineering 33, 78 (2012).

[28] S. Khemakhem, R. Ben Amar, R. Ben Hassen, A. Larbot, M. Medhioub, A. Ben Salah, L. Cot, Desalination 167, 19 (2004).

[29] Y. Anbri, N. Tijani, J. Coronas, E. Mateo, M. Menéndez, J. Bentama, Desalination 221, 419 (2008).

[30] N. Saffaj, S.A. Younssi, M. Persin, M. Persin, M. Cretin, A. Albi, A. Larbot, Ceram. Int. 31, 205 (2005).

[31] S.H. Lee, K.C. Chung, M.C. Shin, J.I. Dong, H.S. Lee K.H. Auh, Mater. Lot. 52, 266 (2002).

[32] S. Rakib, M. Sghiar, M. Rafik, D. Cot, A. Larbot, L. Cot, Ann. Chim. Sci. Mat. 25, 567 (2000).

[33] S. Masmoudi, A. Larbot, H. El Feki, R. Ben Ama, Desalination 190, 89 (2006).

[34] B. Boudaira, A. Harabi, F. Bouzerara, S. Condom, Des. Wat. Treat. 9, 142 (2009).

[35] F. Bouzerara, S. Boulanacer, A. Harabi, B. Boudaira S. Achour, S. Condom, Physics Procedia 2, 1449 (2009).

[36] S.J.G. Sousa, J.N.F. Holanda, Materials Research 8, 197 (2005). 